\title{
Global World Markets in the First Half of 2020: Uncertainties, Trade Slowdown and Forced Protectionism under the Influence of National Isolation Measures
}

Mercados mundiales mundiales en el primer semestre de 2020: incertidumbres, desaceleración del comercio y proteccionismo forzado bajo la influencia de las medidas nacionales de aislamiento

\author{
Rustam Anzorovich Shortanov \\ Financial University under the Government of the Russian Federation, 125993, Moscow, \\ Leningradsky Prospect, 51/1, Russian Federation. \\ ORCID:0000-0002-4710-6510
}

Received 09-08-20 Revised 10-10-20

* Correspondence

Email: shortanoff@yandex.ru
Accepted 12-12-20 On line 03-15-21

\section{Citation:}

Rustam Anzorovich Shortanov. (2021). Global World Markets in the First Half of 2020: Uncertainties, Trade Slowdown and Forced Protectionism under the Influence of National Isolation Measures. Propósitos y Representaciones, 9 (SPE3), e1140. Doi: http://dx.doi.org/10.20511/pyr2021.v9nSPE3.1140 


\begin{abstract}
Global world markets are often influenced by various macroeconomic factors that have both a positive and negative impact on their development. Recently, the whole world is experiencing, without exaggeration, a global economic catastrophe associated with the almost lightning-fast spread of a dangerous virus, the country of origin of which was China. The COVID-19 pandemic has caused unprecedented global upheavals that have had a major impact on societies in cities, countries, and regions. Most countries declared a nationwide lockdown in the first weeks of the pandemic, closing their borders to other countries. Moreover, at a time of global acute need for personal protective equipment, ALV and other medical devices and equipment, both air and sea transport were stopped, which separated the producing countries from the consumer countries. With soaring demand and the impact on supply chains, countries that had previously welcomed joint calls to fight the pandemic have entered a trade war in medical equipment. In the commodity market, the price of oil fell, leading to uncertainty about the future of oil-producing countries, as the end point of the pandemic was still unclear. Overall, the pandemic has been a severe test for the global economy. Due to the development of the pandemic, economists expect an unprecedented decline in industrial production and the percentage share of the stock exchange, rising commodity prices, as well as the possibility of reducing the GDP of a number of countries. While national Governments are trying to offset this drop in commodity prices, as well as for households, firms and financial markets, by providing economic assistance to affected groups, it is clear that such measures are not always viable. It is absolutely necessary to study the impact of COVID-19 on the global financial ecosystem in order to develop an effective trade policy. The danger of a pandemic is also exacerbated by the fact that a crisis in economic relations between countries can lead to political consequences that will cause an aggravation of the political situation in the world. The purpose of the work is to consider the development of world markets under the influence of various factors of uncertainty, the decline in production and trade under the influence of measures of national isolation.
\end{abstract}

Key words: uncertainty factors, trade, protectionism, national isolation, global world market.

\title{
Resumen
}

Los mercados mundiales a menudo se ven influenciados por varios factores macroeconómicos que tienen un impacto tanto positivo como negativo en su desarrollo. Recientemente, el mundo entero está experimentando, sin exagerar, una catástrofe económica global asociada con la propagación casi a la velocidad del rayo de un virus peligroso, cuyo país de origen fue China. La pandemia de COVID19 ha causado conmociones globales sin precedentes que han tenido un impacto importante en las sociedades de ciudades, países y regiones. La mayoría de los países declararon un cierre nacional en las primeras semanas de la pandemia, cerrando sus fronteras a otros países. Además, en un momento de gran necesidad mundial de equipos de protección personal, ALV y otros dispositivos y equipos médicos, se detuvo el transporte aéreo y marítimo, lo que separó a los países productores de los países consumidores. Con la creciente demanda y el impacto en las cadenas de suministro, los países que anteriormente habían dado la bienvenida a los llamamientos conjuntos para luchar contra la pandemia han entrado en una guerra comercial en equipos médicos. En el mercado de materias primas, el precio del petróleo cayó, lo que generó incertidumbre sobre el futuro de los países productores de petróleo, ya que el punto final de la pandemia aún no estaba claro. En general, la pandemia ha sido una dura prueba para la economía mundial. Debido al desarrollo de la pandemia, los economistas esperan una caída sin precedentes en la producción industrial y la participación porcentual de la bolsa, el aumento de los precios de las materias primas, así como la posibilidad de reducir el PIB de varios países. Si bien los gobiernos nacionales están tratando de compensar esta caída en los precios de los productos básicos, así como para los hogares, las empresas y los mercados financieros, brindando asistencia económica a los grupos afectados, es evidente que esas medidas no siempre son viables. Es absolutamente necesario estudiar el impacto de COVID-19 en el ecosistema financiero global para poder desarrollar una política comercial eficaz. El peligro de una pandemia también se ve agravado por el hecho de que una crisis en las relaciones económicas entre los países puede tener consecuencias políticas que agravarán la situación política en el mundo. El 
propósito del trabajo es considerar el desarrollo de los mercados mundiales bajo la influencia de varios factores de incertidumbre, la disminución de la producción y el comercio bajo la influencia de medidas de aislamiento nacional.

Palabras clave: factores de incertidumbre, comercio, proteccionismo, aislamiento nacional, mercado mundial global.

\section{Introduction}

Initially, the development of the incidence of a new type of coronavirus in China was not perceived by the world as a future global threat. However, the almost lightning-fast release of the virus out of control has created an emergency situation of global concern, which has been called a global pandemic since March 15, 2020.

In the first months of 2020, the virus has actively spread from China to Europe, the United States and other countries. The consequences of its spread were large-scale environmental destruction, as well as the death of people. No country in the world was prepared for such consequences. The peculiarity of this pandemic was, first of all - uncertainty factors, a decline in trade and forced protectionism under the influence of national isolation measures, so that the consequences of its spread affected even those countries where a small number of confirmed cases of the disease were registered. This was due to the widespread suspension of international and local transport, which led to the interruption of the supply chains of various products and services, undermining the tourism industry, the manufacturing sector, the education system, etc (Holmdahl \& Buckee, 2020).

As the pandemic spread, cooperation between countries in the fight against the virus expanded. For example, when the epicenter was in China, it received personal protective equipment (PPE) and medical supplies from the United States, its direct trade and energy competitor. In addition, as the situation in the United States began to deteriorate, Russia, its longtime adversary, sent a plane with humanitarian medical aid to help the country counter the spread of the virus.

In addition to sharing medical equipment, countries and organizations provided financial assistance to each other. For example, the Government of Cuba has sent medical personnel to countries such as Italy, South Africa, etc.

Despite the widespread unity, and compassion for those countries that have been significantly affected by the pandemic, the growth of confirmed cases and deaths exponentially countries - began to close their borders and impose strict measures in compliance with sanitary and hygienic measures, populations, and isolation of the population.

Some countries have banned foreigners from entering, and permanent residents and citizens returning from countries affected by the virus have been forced to go into 14-days quarantine. Other states imposed a nationwide lockdown and curfew, and only companies providing socially significant services were able to continue their work. Countries such as Russia, Germany, India, as well as countries in European regions introduced strict requirements and rules that were supposed to regulate the export of personal protective equipment (PPE). Such actions were taken in each individual country and region, as it became clear that the world is experiencing a shortage of personal protective equipment and other medical supplies, despite the increase in the number of infected people (Adhikari et al., 2020).

The shortage of PPE was confirmed by the World Health Organization, which called on countries with manufacturing capacity to cover the shortage in these funds in those countries where the shortage of PPE has caused an increase in deaths among infected people. For example, in Bangladesh, Italy and the United Kingdom, there was a high increase in deaths among health workers working in hospitals where infected patients were placed for treatment, due to the lack of necessary personal protective equipment. 
Shortages and tensions around the world have been caused by widespread lockdowns imposed by countries, which have led to a reduction in global supplies of raw materials and the closure of factories that produce these products. The shortage also arose due to restrictions on transport transfers, both by air, sea and land. These failures in the manufacturing sector and in the supply chain have led to the development of the governments' anti-crisis program, under which introduced tax breaks for the victims of the pandemic, businesses, allocated allowances to families with children, supported by self-employed citizens and companies in the period of the closure had not disbanded his own state, the state was allocated financial support to pay the salaries of employees who were forced to temporarily stop work in the enterprise (Poghosyan \& Beskrovnikh, 2020).

Also, some countries have introduced measures of forced protectionism, manifested through the export of medical supplies. In the US, President Donald Trump even imposed temporary restrictions on immigration to the US to protect Americans from competition in the labor market, as almost 30 million people had filed unemployment claims by April 30, 2020.

These sufficiently justified forms of protectionism demonstrate how the pandemic has exposed the economies of virtually all countries, including the developed ones. The purpose of the work is to consider the development of world markets under the influence of various factors of uncertainty, the decline in production and trade under the influence of measures of national isolation.

\section{RESULTS}

Since the beginning of globalization, the world economy has developed at a fairly high pace, its" engines " have worked without failures and have never stopped, even in times of upheaval in some parts of the globe. But the unexpected happened: the COVID-19 pandemic caused the shutdown of not just a few, but all such "engines" in the world. The inevitable lockdowns and self-isolation, strict border restrictions and travel bans are just some of the main factors that have made the world's engines untenable. Another factor is the growing incidence of coronavirus worldwide and the vague prospects for overcoming the disease and developing collective immunity (Zvonova, 2020).

The problems facing the world began in China, where the coronavirus started slowly, but within days it spread widely and in an unprecedented manner, requiring the closure of all economic activities, including manufacturing sectors and industries. The disruptions in China's factories immediately affected the rest of the world, especially given that a significant portion of all production capacity was concentrated in this country.

Failures occurred at a time when consumer demand for various products in other countries from different parts of the world was at a high level, and he grew up - this demonstrates the report of the UN Conference on trade and development (UNCTAD) shows that exports in 2019 grew by 9.7\% compared to 2018, while China is the leading global trade: volume of exports from China to developed countries amounted to about 8777 billion USD in developing, about 193 billion dollars (Stuart et al., 2019).

When the coronavirus broke out in China, other countries tried to replace the volume of goods previously produced in China and sent for export. But this process was interrupted at the very beginning: the speed of the spread of the coronavirus led to blocking, border restrictions and bans on travel and transport, which served to reduce exports to other countries and regions, even those goods and products that could be produced without the participation of China.

At the same time, demand for a number of products declined significantly, with demand for medical supplies and PPE surging to record highs as shortages of their stocks and export restrictions played a role. Even after China defeated the virus and reopened most businesses, it became difficult to ship manufactured goods, first because of transportation restrictions, and second because of deteriorating economic conditions in different countries, with significant numbers of people losing their jobs around the world (Ibraeva, 2020). 
The supply chain disruption also put enormous pressure on existing products in the market: some faced exponentially increasing demand that could not be met, while demand for other products experienced an unimaginable drop. Among those that have seen an increase in demand are pharmaceuticals, PPE, ALV, and other products needed in the health sectors, especially due to the diverse effects of the coronavirus on the human body. According to a WHO simulation conducted in April 2020, 89 million medical masks, 76 million examination gloves, and at least 1.6 million safety glasses are required every month for the entire global population to meet the health and hygiene requirements in the fight against the virus (Nicola et al., 2010).

In light of the above, it has been proposed in the US to force major companies such as General Motors (GM) to produce ALV through an executive order to fill the gap created by the growing number of confirmed cases of coronavirus. Later, the company was joined by others, such as Ford and Tesla, who helped the government mass-produce urgently needed ALV and other medical supplies. In Europe, automakers have teamed up to help create fans, which have been growing rapidly in demand with very limited supply.

In countries where oil production is developed, the impact of COVID-19 on various sectors of the economy, such as transport and industrial production, has led to a significant drop in demand for oil and petroleum products. The rate of decline in prices in this sector was $55 \%$, while oil prices in the United States for the first time in history fell below zero US dollars.

In the US, crude oil prices fell from $\$ 38$ a barrel to a low of $\$ 18$ just hours after a supply glut caused by a lack of storage facilities emerged. In Canada, this figure fell by about $74.07 \%$ in just 1 month from \$12.84 per barrel to \$6.51 per barrel between March 2020 and April 2020.

The drop in prices has even prompted OPEC to consider cutting its production capacity to offset losses and overproduction. However, this step was not properly understood in the market.

While countries rushed to impose nationwide lockdowns and restrictions on the transport sectors, leaving only a few major service providers to operate, their actions immediately affected the development of the energy sector. In many countries, including China, the United States, and countries in Europe, energy demand plummeted, causing a subsequent crash in oil markets. At the same time, for the first time in history, pressure on the oil market required a reduction in production to contain losses caused by lower oil prices, as well as lower demand. According to the International Energy Agency (IEA), in April alone, global oil demand fell by an average of 29 million barrels, calculated to be lower than demand for the same period last year. This decline was the lowest since 1995. The price of crude oil in April also fell to a historic low of 37 US dollars, which means that producers were forced to pay oil buyers for its export and consumption (Pekhtereva, 2020).

As a result, to stabilize the oil market, OPEC and its allies have reached an agreement to reduce production by about 9.7 million barrels per day $(\mathrm{mb} / \mathrm{d})$ starting on May 1, 2020, which is also the largest reduction in oil production in history. The Agreement stipulated that each participant should reduce their normal daily oil production, so that when accumulated, the total reduction would be 9.7 million barrels per day. For example, Mexico agreed to reduce daily production by 400,000 barrels per day and maintain this production for 2 months (May 1 - June 30). Daily oil production, according to the Agreement, shall not exceed a rate of $7.7 \mathrm{mb} / \mathrm{d}$. The period of validity of the Agreement was designated as the time period from July 1 to December 31.

Since the discovery of oil and the subsequent increase in demand for it in various sectors of the economy around the world, oil has always been a highly valued commodity, and oil-producing countries have demonstrated high economic growth over the years. In particular, most of the countries in the Persian Gulf region can explain their high economic growth by their oil reserves. But the unexpected outbreak of COVID-19 and the subsequent rapid spread of the coronavirus have confounded these economies, as their economic survival paths have been threatened by low oil demand. The most difficult point in this matter is the uncertainty about how long the COVID-19 crisis will last and how much it will bring down the oil market. Accordingly, it will take a long time before the oil market in most countries will recover to the previous volumes. 
At the moment, the oil market, presented as one of the sectors supporting the economy, is stagnating in many countries, forcing governments to consider plans to save it. Judging by the way OPEC and its allies have developed their recommendations, it may take a considerable time before the industry returns to its previous economic performance. The situation will even worsen if the recession, which is predicted to replace the COVID-19 crisis, is updated. In this regard, from a historical point of view, recessions have always had a bad impact on the oil and energy market, and 2021 will be no exception. Moreover, if different countries, regions and economies decided to exit the oil-dependent economies by switching to renewable energy sources, it would mean a positive view of the new global political and economic landscape. But this will be a negative scenario for oil-producing countries, which will also recover from both the effects of COVID-19, which significantly affected them, and from the recession.

Another problem in the global economy, expressed in the disruption of the supply chain, can be demonstrated by the example of the production of medical products. The growth rate of morbidity in the period April-May 2020 in the world was quite high, and at the same time the shortage of medical supplies continued to be quite high. At first, this deficit was explained by a reduction in the production of this type of product. For the most part, this was attributed to China after the country imposed a lockdown on the scale of all regions where there was a hotbed of the disease, as well as restricted any form of activity, except for the supply of basic necessities. Later, starting from the end of March 2020, the country's manufacturing sector gradually returned to work, reaching a production capacity of almost $80 \%$ by mid-April 2020 . But even as China's enterprises began to produce the world's much-needed medical supplies, they faced an unprecedented challenge in the supply chain as the borders of most countries closed. Although regular transport links are established between China and other countries located in different parts of the world, thanks to air and sea routes, the movement of manufactured goods has become an unexpected problem (Belov, 2020).

As problems with the supply of medical supplies increased, so did the shortage, especially as the number of people in need of hospitalization grew rapidly. In some countries, in order to replenish the dwindling stocks of PPE and other medical supplies, local manufacturing sectors were engaged at maximum production capacity, but still their efforts were not enough to meet the growing demand. For example, in the United States, Prestige Ameritech, the largest manufacturer of medical masks, together with other small manufacturing companies, launched their production facilities at full capacity to meet the demand for more than 300 million medical masks, but the actual production volume was no more than 50 million masks. The situation was not improved even by Trump's application of the provisions of the Defense Production Act (DPA) to large manufacturers of PPE in the United States to force them to increase their production capacity and stop exporting any masks outside the country.

A similar situation also occurred in Europe: local companies, manufacturers of PPE, did not expect a pandemic and were not prepared for such a surge in demand for these products.

In the face of a shortage of medical supplies, the governments of most countries have decided to force both specialized and non-specialized companies to give priority to their production, as well as to establish strict control over the shipment and supply of these products in order to reduce their export abroad. In particular, in the United States, control over the movement of a medical drug was transferred to the Federal Emergency Management Agency (FEMA). In the United Kingdom, Prime Minister B. Johnson called on car manufacturers in the country to give priority to the production of fans and other technical specialized medical devices for hospitals. In the Czech Republic, the government adopted the same approach as the governments of Russia, India and Germany, banning the export of medical products.

In some cases, national Governments have even been accused of using behind-the-scenes tactics to ensure that their citizens are provided with PPE. For example, the US government was accused by the local Berlin government of "piracy" for confiscating and forcibly returning more than 200,000 purchased by the German government back to the country. In addition, under unclear circumstances, more than 6 million masks, also purchased for their citizens by the German government, disappeared at the airport in Kenya (Roy \& Ghosh, 2020). 
In South Korea, anyone involved in the concealment and profiteering of masks or other medical items in high demand in hospitals was guaranteed 2 years in prison or fines of up to $\$ 42,000$. In Indonesia, security officials were forced to search the homes of citizens after it turned out that people were buying masks for the future, to store them until the prices for them do not rise, and it will be possible to sell them more expensive. In particular, the Indonesian police seized a batch of 600,000 masks at one of the warehouses and arrested the owners of this warehouse, who, in addition to imprisonment, had to pay a large fine for their actions.

These and many other actions and strategies that governments around the world have taken in this area demonstrate that medical supplies are now considered essential goods (Randhawa et al., 2020).

\section{Discussion}

With the increased pressure on trade, which has prompted governments to take unprecedented and decisive actions like those discussed earlier, all aimed at protecting public health, social and economic stability, there has been little relative global government action of meaningful significance. In particular, it was noted that each Government has formulated and implemented its own unique policies and measures, regardless of what their neighbors, trading partners or competitors are doing or what policies they are implementing.

The specific aspect of the approaches chosen by each Government is that they are all designed to fight a common enemy that could be defeated much more easily if there were global coordination and unity. On the contrary, the single approach of Governments causes divisions and disharmony at the local, regional and international levels, which pose a threat to global security. For example, before the appearance of the coronavirus in Wuhan, China, the United States, and China were involved in trade wars, resulting in the US banning goods from China and imposing heavy taxes on other countries. But the rivalry between these global economic giants was reignited by the emergence of the coronavirus, when the US accused China of hiding information about the emergence and spread of the disease. The disharmony escalated when the United States cut off funding for the World Health Organization (WHO)and accused the latter of collaborating with China to misinform the world about the virus.

Since it is not known when the COVID-19 crisis may end, and given the existence of numerous problems, such as staff shortages in the health sector, unemployment, social tensions when people are tired of staying at home, and other problems, there are concerns that the economic and trade crisis may be exacerbated by political problems. In China, for example, as early as the early summer of 2020, local residents repeatedly reported violent attacks on minority groups (mostly Africans): they were driven out of their apartments and prevented from accessing restaurants, food stores and other facilities. In Heilongjiang Province, China, there was an increase in disagreements between local authorities and the Russian government over the suspension of the Suifenhe land port due to cases of coronavirus infection from Chinese citizens returning from Russia. The suspension of the port meant restricting the movement of trade in the border cities between the two countries; for this reason, the Russian side threatened to deport Chinese citizens [12].

Accordingly, the crisis in economic relations between the countries may entail political consequences that will lead to an aggravation of the political situation in the world.

\section{Conclusions}

Due to the development of the pandemic, economists expect an unprecedented decline in industrial production and the percentage share of the stock exchange, rising commodity prices, as well as the possibility of reducing the GDP of a number of countries. While national Governments are trying to offset this drop in commodity prices, as well as for households, firms and financial markets, by providing economic assistance to affected groups, it is clear that such measures are not always viable. It is absolutely necessary to study the impact of COVID-19 on the global financial ecosystem in order to develop an effective trade policy. 


\section{References}

A. Saglietto, F. D'Ascenzo, G.B. Zoccai, G.M. (2020). De Ferrari COVID-19 in Europe: The Italian lesson Lancet, 395, 1110-1111

Adhikari, S. P., Meng, S., Wu, Y. J., Mao, Y. P., Ye, R. X., Wang, Q. Z., ... \& Zhou, H. (2020). Epidemiology, causes, clinical manifestation and diagnosis, prevention and control of coronavirus disease (COVID-19) during the early outbreak period: a scoping review. Infectious diseases of poverty, 9(1), 1-12.

Belov, V.B. (2020). Consequences of the coronavirus pandemic for the German economy. Scientific and Analytical Bulletin of the Institute of Europe of the Russian Academy of Sciences, 2.

Holmdahl, I., \& Buckee, C. (2020). Wrong but useful-what covid-19 epidemiologic models can and cannot tell us. New England Journal of Medicine, 383(4), 303-305.

Ibraeva, E. A. (2020). The world economy after the pandemic / / Vestnik nauki i obrazovaniya, №181 (96).

Nicola, M., Alsafi, Z., Sohrabi, C., Kerwan, A., Al-Jabir, A., Iosifidis, C., ... \& Agha, R. (2020). The socioeconomic implications of the coronavirus and COVID-19 pandemic: a review. International journal of surgery.

Pekhtereva, E.A. (2020). The impact of the coronavirus pandemic on the Chinese economy. No. 3.

Poghosyan, A.A., \& Beskrovnikh, D. S. (2020). Pandemic as a factor of economic crisis. New impulses for development: issues of scientific research, 6-1.

Randhawa, G., Soltysiak, M., El Roz, H., de Souza, C., Hill, K., Kari, L. (2020). Machine learning using intrinsic genomic signatures for rapid classification of novel pathogens: Covid-19 case study PloS One, 15(4), Article e0232391.

Roy, S., \& Ghosh, P. (2020). Factors affecting covid-19 infected and death rates inform lockdownrelated policymaking PloS One, 15(10), e 0241165.

Stuart, D., Gunderson, R., Petersen, B. (2019). Climate change and the Polanyian countermovement: carbon markets or degrowth? New Polit Econ, 24, 89-102

Zvonova, E.A. (2020). Transformation of the world economy and the pandemic. Economy. Taxes. Right, 4. 